\title{
第16回日本正常圧水頭症学会を岡山で開催して
}

\section{Hosting the 16th Annual Meeting of the Japanese Society for Normal Pressure Hydrocephalus}

会長 伊達 勲（岡山大学大学院医歯薬学総合研究科 脳神経外科学）

Isao Date (Department of Neurological Surgery, Okayama University Graduate School of Medicine, Dentistry and Pharmaceutical Sciences)

第16回日本正常圧水頭症学会を2015年 2 月28日 (土) (プレミーティングセミナーは 2 月 27 日 (金)) に会長 として岡山コンベンションセンターで主催いたしまし た。全国から脳神経外科医, 神経内科医, 放射線科医 など250名が参加し, 活発な討論が行われました。外科 治療が有効な認知症, 歩行障害として注目をあつめて おります正常圧水頭症について討論する本学会を, 岡 山で開催することができましたことを大変光栄に存じ ますとともに, 学会が成功裏に終了しましたことを関 係の皆様に深く感謝申し上げます。

正常圧水頭症の病態解明, 治療法開発, 社会への啓 蒙など，本学会がこれまで果たしてきた役割は大きい ものがあります.さらにこの数年, 学会主導で行って きた臨床研究 SINPHONI study などを契機に, 正常圧 水頭症に関するデバイス, 手術手技, 分類, 画像診断, 取り巻く社会環境などに新しい側面が見えてきまし た。そこで今回の学会のテーマを「正常圧水頭症の新 展開」とし演題募集しましたところ, 73 題という多数

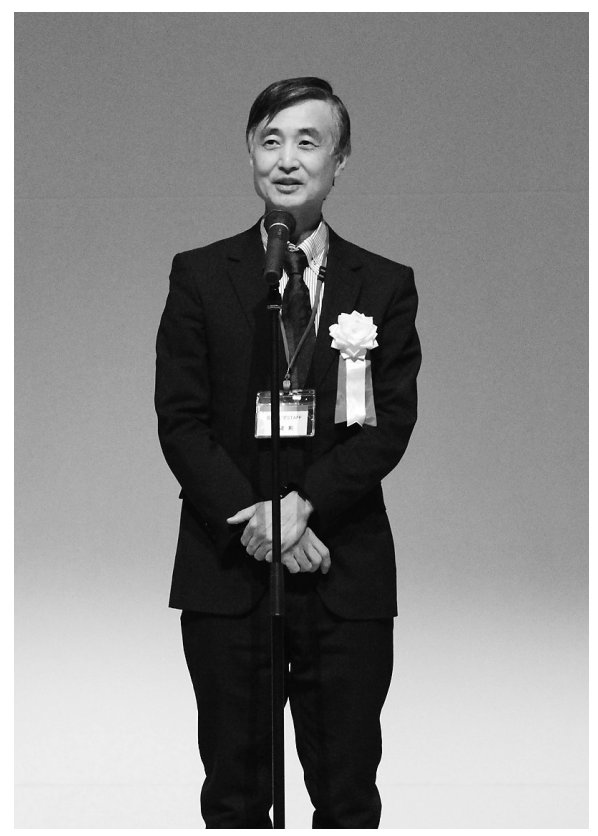

会長挨拶（伊達 勲）
の演題を応募いただき，1日でこなすのはなかなか大 変でしたが，2 会場で熱心な討論がなされました。

教育講演を 2 題お願いいたしました。東海大学脳神 経外科の松前光紀先生には「脳脊髄液の動きを可視化 する」と題してお話しいただきました，脳春髄液の動 きを画像でとらえようとする試みについて，その歴史 からはじまり，最先端の研究までまとめていただき， 大変勉強になりました. MRI の応用で脳内の髄液の流 れはかなりのレベルまで可視化できるようになってお り, 治療法の決定や, 治療効果の判定に大いに役立つ と思われます。藤田保健衛生大学リハビリテーション 学科の大塚 圭先生には,「歩行障害を客観的に診る」 をお話しいただきました。歩行分析の方法論は，歩行 障害を主訴の一つとする正常圧水頭症の病態解析, 治 療効果の数值化に直結します. 先生の方法は, 患者の

\section{第16回日本正常压水頭症学会}

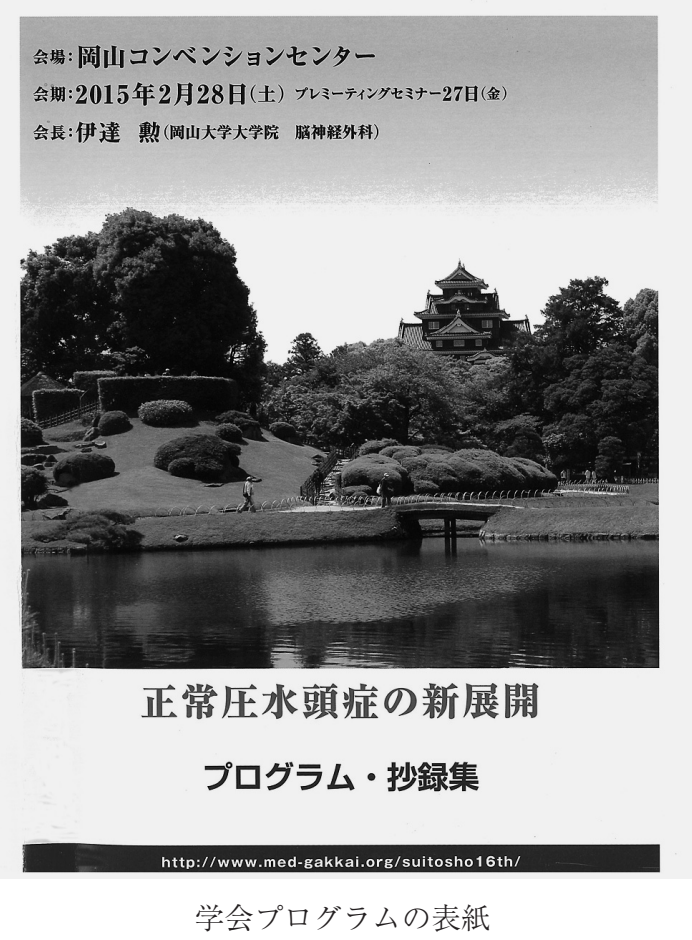




\section{第16回日本正常圧水頭症学会}

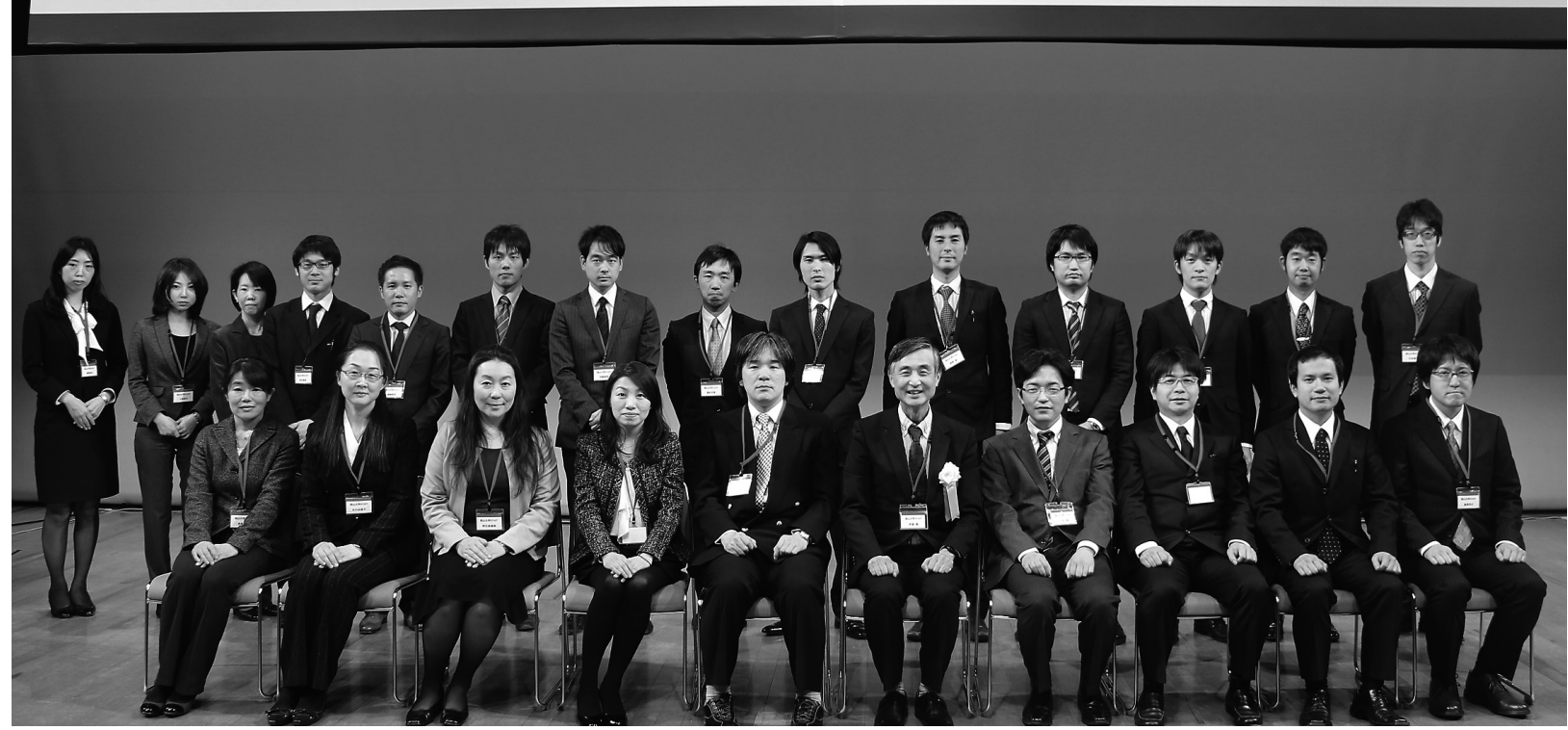

学会運営してくれた岡山大学脳神経外科のメンバー

三次元トレッドミル歩行をリサージュ概観図という方 法でデジタル分析するもので, 現在一般的に行われて いる歩行秒数の測定などに加えて, 今後大きな役割を 果たす期待が持たれます。

正常圧水頭症と同様, 歩行障害が重要な症状である 疾患にパーキンソン病があります。脳深部刺激療法, 脊髄刺激療法はいずれも電気刺激療法としてパーキン ソン病の治療の重要な手段です.ランチョンセミナー では, 順天堂大学脳神経外科の中島 円先生と, 岡山 大学脳神経外科の上利 崇先生に,「正常圧水頭症診療 に役立つ電気刺激療法 update」と題してお話しいただ き, 正常圧水頭症診療に携わる各科の先生方に大いに 役立つ内容でした。

プレミーティングセミナーでは, 一般演題でカバー しきれないような領域を含め, エキスパートの先生方 からじっくり教育的な括話しをうかがうことができま した. 正常圧水頭症は歩行障害が主症状の一つである ため, 患者の転倒には十分気をつけなければなりませ ん. 日本転倒予防学会理事長の武藤芳照先生に「転倒 予防の理念と実践」をお話しいただき, 普段の患者管 理に注意すべき事を学びました。パーキンソン病など の診断に最近注目を集めているDAT scan ですが, 認
知症の鑑別にも役立つことがあります。順天堂大学神 経内科の本井ゆみ子先生には「DAT scan を用いた認 知症の鑑別診断」と題してお話しをいただきました。 脳神経外科の分野からは, 恵み野病院の貝嶋光信先生 に「術後改善率向上のための基本戦略」, 多摩北部医療 センターの岡田隆晴先生に「外来でiNPH を見逃さな いためのポイント」, 公立能登総合病院の橋本正明先生 に「院内転倒とDESH 所見との関係」をお話しいただ き, 正常圧水頭症の診療に携わっている会員に益する ところ大でした。

「正常圧水頭症」という一疾患を扱う学会ですが, 今回のテーマの「正常圧水頭症の新展開」に相応しい 沢山の演題を発表いただき,一日中熱心な討論が続き ました。学会としての臨床研究であるSINPHONI studyの成果もサブ解析を含め沢山論文発表がなさ れ，この分野の盛り上がりが感じられます. 岡山大学 脳神経外科でも引き続き本疾患について研究を続けて いきたいと思います。

平成 27 年 8 月受理

T700-8558 岡山市北区鹿田町 2-5-1

電話：086-235-7336 FAX : 086-227-0191

E-mail :idate333@md.okayama-u.ac.jp 